\title{
An Unsettled Majority: Immigration and the Racial "Balance" in Multicultural Singapore
}

\author{
Mark R. Frost \\ University College London
}

In 2013, the Government of Singapore confirmed a long although mostly private assumption that it intervened through its immigration policy to maintain the city-state's racial "balance"that is to say, the ethnic ratios that had existed from before Singapore's political independence and that placed its Chinese community in a demographic ascendancy at three-quarters of the total population. ${ }^{1}$ Grace Fu, a Minister in the Prime Minister's Office, stated:

It is our policy to maintain the ethnic balance in the citizen population as far as possible.... We recognize the need to maintain the racial balance in Singapore's population in order to preserve social stability. The pace and profile of our immigration intake have been calibrated to preserve this racial balance. (Straits Times, February 5, 2013)

Prime Minister Lee Hsien Loong soon after issued a statement of his own: "We will preserve the Singapore character of our society. In particular, we will maintain the ethnic balance of our citizen population" (Straits Times, February 9, 2013).

Official explanations of the determinants of Singapore's immigration intake had, until these announcements, remained opaque. In 2009, former Prime Minister Lee Kuan Yew, while serving as Minister Mentor, explained that the government was conscious that it needed "to keep the character and values of Singapore society" by "carefully controlling" the island's resident population through its regulation of Permanent Residents (PRs) and new citizens. ${ }^{2}$ Most other official utterances gave little hint that migrant selection, permanent residency, or 
naturalization were, or would be, ethnically determined. Instead, such pronouncements generally focused on economic development, dwindling fertility rates, and an ageing population as the key factors that shaped the state's approach to immigration and permanent settlement (Teo Chee Hean, DPM's Speech 2010).

However, once the government had let the metaphorical immigration "cat" out of its policy bag, Singaporean citizens who had understood the Republic to embody a more colourblind idealism expressed their surprise and indignation. Sudhir Thomas Vadaketh, a Singaporean Indian writer, observed that Singapore possessed "THE most racist [immigration] policy in the developed world" (Vadaketh 2015). In the island's popular Today newspaper, a correspondent by the name of Sum Siew Kee wrote:

This means that we are allowing many Chinese and Indians to immigrate to Singapore, compared with other migrants. Does this not go against our well-regarded meritocratic principle? If, say, more talented Indians than talented Chinese are interested in coming here, should we not let them do so, regardless of ethnic quotas? We should also have more migrants from the region to build up ties with our neighbouring countries. South-east Asia is still our hinterland. This means we should be more welcoming towards Thais, Vietnamese, Filipinos and Indonesians, among others. This would help Singapore integrate with one of the world's fastest growing regions. We should have fewer qualms about mere quantity and quota, but focus on building racial harmony among people in Singapore, no matter where they come from. (Today, February 15, 2015)

The government had made clear its commitment to racial "balance" in the context of widespread opposition to its 2013 Population White Paper, which announced that Singapore would grow its population from its (then) 5.3 million to 6.9 million by 2030 , an increase of roughly one hundred thousand inhabitants a year, with immigrants intended to make up nearly 
half of that figure. The White Paper itself contained no mention that immigration was to be, and had been historically, calibrated to maintain the city-state's ethnic composition. That announcement was made to allay fears amongst Singapore's minority Malays that they would be swamped by new Chinese and Indian arrivals. Yet in providing such reassurance, the government afforded an insight into its approach to multiculturalism (or, to use its own preferred vocabulary, "multiracialism") and the importance it placed on adhering to static and putatively harmonious ethnic ratios.

In a Western context, how liberal states manage multicultural populations to ensure harmonious and equitable national communities has produced much scholarly debate, especially following the ground-breaking theorizing of the Canadian philosopher Will Kymlicka concerning minority group rights (Kymlicka 1989, 1995). Such debates, as Stephen Nagy has observed, have resonated far less in Asia, where multiculturalism, as understood and applied in the Western liberal context, has not been "the preferred model" (Nagy 2014). Nevertheless, Singapore remains for many observers a striking Asian multicultural success story, especially when set against the backdrop of the communal violence that blighted the paths of its regional neighbours from decolonization into independence (notably Sri Lanka, India, and Indonesia). In his survey of "East" Asian approaches to multiculturalism, Nagy recognizes Singapore for its "pragmatic" yet, in his view, "egalitarian" approach, fuelled by the need to ensure "harmony and balance" and "economic integration."

Nagy does acknowledge tensions in the Singapore model, especially regarding the position of the island's Malay community and relations between national citizens and new immigrants. Other scholars have been more openly critical. Michael D. Barr argues that official Singaporean multiculturalism has perpetuated the increasingly hierarchical racial imaginary of the ruling PAP (People's Action Party), in which a dominant Chinese elite finds its natural place at the top of society and a Malay underclass at the bottom, and thus undermined the 
meritocratic idealism on which the independent nation was founded (a point that we will further explore later). Barr also argues that the official Singaporean rhetoric of multiracialism has masked an "aggressive" state-led "programme of assimilation of the racial minorities into a Chinese-dominated society," as evidenced through state efforts in the 1980s to install Confucianism as a national ideology (Barr and Skrbis, 2014, 9-11, 82-97). In a similar vein, Chua Beng Huat (2003) explores "the complex configuration of multiculturalism in practice" that rationalises inequalities in Singapore in the name of maintaining racial "harmony," while Goh and Holden (2009, 1-16) critically unpick the PAP's "racial governmentality". As one of their contributors puts it, multiculturalism in Singapore, in as much as it has been directed toward "guaranteeing equal rights and treatment" for the island's various ethnic groups, "is also, however, about maintaining the relative population strength of each racial segment of CMIO [Chinese, Malay, Indian and Other]" (Goh and Holden, 73).

But striking in such analyses is how little immigration as a tool of racial governmentality features. Some authors recognize that to ensure the racial "balance" in Singapore the state has been forced into deft efforts at official "racial arithmetic" (Yeoh and Chan 2001, 1041), with one prominent scholar labelling official efforts to maintain the ethnic status quo a governmental "fetish" (Chua 2003, 69). Yet scant analysis has probed the function of Singapore's racialized immigration approach in producing this intended status quo, or ultimately (as we will argue) in undermining it. This lacuna has made possible uncritical studies which appear to absorb the government's presentation of its multicultural and immigration policies at face value. Hill and Lian, in their 1995 discussion of the politics of nation-building and citizenship in Singapore, attest to the "liberal" and "inclusive" features of its immigration policies, "in the sense that migrants with occupational skills are welcome, and after a short period of residence are granted citizenship" (Hill and Lian 1995, 96), seemingly oblivious to the system of ethnic quotas that the government (in reality) has long enforced. Likewise, 
Shirley Sun, in a more recent study of Singapore's population management (one that largely avoids grappling with the question of ethnicity), reinforces the assumption that economic factors have primarily driven the island's immigration and citizenship policies (Sun 2012, 11$12,135-136)$.

A key exception is research by Nasir and Turner (2014, 24-28), which stridently asserts that Singapore's immigration policies are driven by the "logic" of a system in which "the category of race is the crucial barometer for conferring citizenship and residency," and in which migrant population boosts are specifically deployed "to sustain the historical dominance of the Chinese in the tripartite racial structure of Chinese-Malay-Indians in Singapore." But even in this valuable survey, there is little in-depth discussion of the origins of such "logic" as it applies to immigration, of how such "logic" has been officially expressed and disseminated, or of what it ultimately signifies about official multiculturalism in Singapore, in practice as opposed to rhetorically.

This essay seeks to fill that gap by situating the emergence of Singapore's immigration and racial "balance" policies within a longer history of demographic change, and a longer history of racialized official discourse dating back to the colonial past. Having established such a context, we examine how the Singapore government has legitimized its efforts to maintain racial "balance", the revealing political contests these efforts have produced, and the international and domestic fallout that has resulted. In the final part of this essay, we consider the way reductionist official understandings of ethnicity, deployed by the state in its pursuit of racial "balance", have subverted its efforts at social integration and harmony, leading to the emergence of a periodically unsettled Singaporean Chinese majority.

A primary aim of this essay is to complicate the picture that scholars have thus far painted to explain Singapore's static tripartite ethnic structure. In this picture, the state's 
preoccupation with fixed ethnic ratios is tied to the geopolitical reality Singapore has faced since its independence in 1965 , when it emerged as a small independent nation with a majority Chinese population surrounded by larger nations dominated by non-Chinese majorities (Rahim 2010, 78-111; Chua 2003, 69). The necessity of fixed ethnic rations then became reinforced from the 1980s, as the government moved to bolster Singaporean "Chinese-ness" (through both its education and immigration policies) to ensure the city-state could effectively function as a Western trade bridge into China, a global gateway to a new capitalist Cathay (Montsion 2009). To these geopolitical and economic explanations, this essay adds a sociocultural dimension, by rooting the "logic" of Singapore's immigration and racial "balance" policies within a practice of imagining history, and imagining "cultures," "civilizations," and "races" historically, that betrays the continuing influence of colonial discourse.

The making of a Chinese majority: labour, capital, and colonial discourse

How did Chinese come to comprise Singapore's dominant ethnic majority? As much as structural, macrolevel economic forces that were left to run free through the laissez-faire attitudes of colonial administrators played a part, official decision-making rooted in the racial discourse of the era was equally responsible.

When the British arrived in Singapore in 1819, the island was a relatively uninhabited territory of the Johor-Riau-Lingga sultanate with an estimated population of between one hundred and one thousand, made up mostly of Malay orang laut (sea people), with fewer than thirty Chinese. Two years later, the population was believed to comprise 4,724 Malays and 1,150 Chinese, and in the first census of the settlement in $1824,6,505$ of the total population of 10,683 were recorded as Malay and Bugis (i.e., over 60 percent). By the mid-1830s, however, the Chinese had become Singapore's majority ethnic group, with a community that 
numbered 13,749, while the broad grouping of peoples defined as "Malay" (including orang laut, Bugis, Javanese, and others) totalled 12,538 (Buckley [1902] 1984, 151; Turnbull 2012, 46; Saw 2012, 28-29).

The discovery of tin in the Malayan hinterland in the 1840 s accelerated this demographic ascendancy. Historically, tin had been mined in Southeast Asia through Chinese enterprise. Chinese tin miners entered Singapore on their way to Malaya, adding to the population of Chinese drawn to work pepper and gambier plantations on the island and in neighbouring Johor and Sumatra. Regionally, these sectors of the economy had received periodic influxes of Chinese labour since the early 1700s. By the late $19^{\text {th }}$ century, Singapore had become the region's primary Chinese immigration entry point, as well as its primary tin extraction point and then smelting centre. In 1871, the year of the first formal colonial census, the Singapore population was 57.6 percent Chinese. By 1901, Chinese made up 71.8 percent, Malays 15.8 percent, Indians 7.8 percent, and Europeans and Eurasians (later referred to by Singaporean census-makers as "Other") 3.5 percent, of a total population that had risen to 228,555 (Saw 2012, 28-30).

Singapore was, in fact, the most recent, albeit intense, example of a process witnessed across Southeast Asia since the arrival of European powers in the early $16^{\text {th }}$ century. From Portuguese Melaka to Spanish Manila to Dutch Batavia, Western expansionism depended on the alliances forged between overseas Chinese and European capital. Chinese investment, labour, local knowledge and provisions were crucial in the establishment of new European colonies. For centuries, the regional networks Chinese merchants commanded made them the Europeans' go-to community for the sourcing of desired goods and produce.

Once Sir Stamford Raffles established his East Indian Company factory in Singapore in 1819 , the settlement began to function, as Penang and Melaka had done before it, as a type 
of Anglo-Chinese condominium. Early colonial Singapore was soon settled by Melakan Chinese, who followed Major General William Farquhar, the cofounder of Singapore's East India Company factory, when he departed Melaka to serve as the island's first British Resident. Many of these Melakan Chinese had learnt enough English to function as intermediaries between European and Malay and Bugis traders. Following their arrival in Singapore, some Melakan Chinese formed joint Anglo-Chinese trading companies with their European partners (Frost and Balasinghamchow 2009, 91-97). From the 1840s, Chinese towkays also acted as labour suppliers for Singapore and Malaya's major tin-mining and plantation enterprises. The nineteenth-century Chinese indentured labour system into and through Singapore was effectively run by Chinese recruiters, in contrast to the contemporaneous Indian indentured labour system which saw greater direct colonial involvement.

As noted, the British commitment to unimpeded immigration and free trade-ist nonintervention in the local labour market also sealed Singapore's path toward a three-quarters Chinese majority. The situation was the same as in in late $19^{\text {th }}$ and early $20^{\text {th }}$ British-ruled Colombo and Rangoon, where shifting domestic and overseas labour demands generated similarly erratic urban demographies. In Singapore, no effort was made to regulate immigration until 1928, when fears of an impending slump in the tea and rubber industries convinced the British authorities to establish migrant quotas under the new Immigration Act of that year. Following the global economic crash of 1929, and with local unemployment rising along with fears of labour unrest, these quotas were introduced for male Chinese immigrants. (Until 1938, however, quotas were not applied to Chinese women and children, whom colonial officials thought to be a stabilizing social influence on the male-dominated population). Consequently, Chinese arrivals in Singapore dropped from 195,613 in 1929 , to 151,613 in 1930 , and to 49,723 in 1931, the year the monthly quota was reduced from 5,238 to 2,500 per month (Low 2014, 3). Nonetheless, in 1931 the population of Singapore stood at 557,745, with Chinese still 
constituting 418,640 (75 percent) of this total, Indians 50,811 (9.1 percent), and Malays 65,014 (11.7 percent) (Yeoh 2003, 17).

Yet, while Singapore's demographic transformation reveals broader historical and economic processes at work, it was hardly inevitable. A critical juncture occurred in 1823 when Dr John Crawfurd succeeded Farquhar as Singapore's second British Resident. Raffles, before he arrived on the island, had been suspicious of the Chinese, regarding them as "deceitful" and disruptive. His experience as a colonial governor in Java led him to argue that Chinese ascendancy in the region "should be cautiously guarded against and restrained" and that British efforts should focus on "bringing forward the native population of Malays and Javanese" by encouraging them "in useful and industrious habit" (Raffles 1835, 82-83). After his arrival in Singapore, Raffles encouraged Hadhrami Arab merchants to settle and trade there, hoping that this would encourage local Malay commerce and industry, not to mention the overall revival of Islamic Malay civilization.

Crawfurd, in contrast, encouraged Chinese settlement in Singapore. Moreover, in making the case for greater Chinese immigration, Crawfurd bequeathed Singapore an additional legacy. On a visit to Penang, he felt it opportune to measure the industry of the Chinese in Singapore's neighbouring Straits settlement against that of the Malays and Tamil Indians settled there, employing a method that compared the pecuniary worth accorded to the labour of each group locally by that same group and by others. Having adjudged the Chinese to possess a higher labour value than Malays or Tamils through this formula (and by virtue of this a higher civilizational status), Crawfurd published his findings for the benefit of his peers and fellow colonial adventurers (Crawfurd 1830, 23-24, 29-32).

Most British officials in Singapore subsequently agreed with the second British Resident. The evidence before them was the greater experience Chinese merchants had with 
capital investments, speculation, and cash transactions when compared to Malay and Bugis traders who had preferred to conduct business through barter. The foundation of a racial discourse that would dominate for the next century and a half was set in place. As we shall discuss, its echoes would from the 1980s appear in the official rationale for maintaining Singapore's racial "balance", and so shape a uniquely Singaporean model of modern multiculturalism.

\section{Governing diversity: multiculturalism as nation-building}

A second discursive legacy that British rule seems to have bequeathed independent Singapore is the notion that managing the island's diverse population demands authoritarianism. As historian Tim Harper notes (citing the Malaysian sociologist Syed Hussein Alatas), a "founding idea of Singapore was that the enlightened reforms necessary to elevate a civilization and to govern a fluid migrant world did not derive from or imply political liberalism but rather necessitated strong government" (Harper 1997, 283). Both colonial and postcolonial rulers in Singapore have presented themselves as the benign despot-arbitrators ensuring the pax between ethnicities deemed primordially antagonistic (Vasu 2012). As Chua argues, the discourse of tenuous racial harmony is one Singapore's authorities continue to deploy to legitimize their racialized governance of the population and the suppression of public discussion of "the difficulties which face all multiracial societies": "Drawing on the instances of race riots in the past, the government constantly warns the population of the 'tenuousness' or racial harmony, thus justifying a need for the constant policing of racial boundaries” (2003, 74-75).

Of course, a key distinction between the past and the near present is that colonial officials, not always explicitly driven by the imperatives of divide et impera but certainly always conscious of them, hardly sought the social integration of Singapore's population into 
a unified body politic. Rather, they envisaged colonial Singapore from the outset as an ethnically segregated settlement. Raffles' original plan for the town, introduced in 1823 , established separate urban enclaves for its various ethnicities (Frost and Balasingamchow, 2009: 64-66). The British continued the Dutch kapitan system of governance with respect to local immigrant populations, which involved establishing separate alliances with the community leaders of these populations and giving their kapitans a significant degree of autonomy to rule over their distinct enclaves. As the colonial scholar-official J. S. Furnivall (1939) observed, Dutch and British colonies in Southeast Asia existed as "plural societies" in which distinct ethnic groups came together to trade but were otherwise unable to think or act collectively. For Furnivall, the dysfunctionality of such plural societies raised major issues regarding social equity and welfare.

For Singapore's emergent post-war nationalist leadership, overcoming such social dysfunctionality, as they looked toward the task of postcolonial nation-building, became the key challenge. From the founding of the PAP in 1954, Lee Kuan Yew and his mainly Englisheducated lieutenants made the creation of a Singapore that belonged equally to all its citizens, regardless of their ancestry, the party's core foundational principle (see Gest, this issue). How this foundational principle became a social reality following Singapore's self-government in 1959 and then full independence in 1965 , is a story Singaporeans have never been allowed to forget. As recently as 2017, Lee's son, Prime Minister Lee Hsien Loong, sensing that the nation required a refresher course, went over this narrative again, in a lengthy speech-cum-historylesson which captured the essential elements of the island's official understanding of its multicultural success (Today 2017). ${ }^{3}$

Lee Hsien Loong recalled that at independence Lee Kuan Yew had declared that "Singapore is not a Malay nation, not a Chinese nation, not an Indian nation. Everybody will have a place in Singapore.” The Singapore Pledge, which committed Singaporeans to building 
a just and equal nation as "one united people regardless of race, religion or language" was rolled out the following year to thereafter become the starting ritual of every school day. An amendment to the constitution in 1969 created what became known as the Presidential Council for Minority Rights, with powers to vet all parliamentary legislation to ensure it was nonprejudicial toward any racial or religious community, and with (as yet unused) powers to veto legislation that failed to meet this standard. To underline Singapore's commitment to its foundational multicultural ideals, Malay was retained after 1965 as the official language of state, and the Malay former journalist Yusof Ishak was appointed Singapore's first president.

In his speech, Lee the younger then asked, "Why was this principle so important to us?":

First, this was the fundamental ideal over which we fought with the central government in Malaysia. Our founding fathers-Lee Kuan Yew, Goh Keng Swee, S. Rajaratnam, Othman Wok-they believed passionately in the vision of a multiracial society. Where nobody would be favoured or disadvantaged because of the colour of his or her skin. Where everybody would have equal opportunities, feel kinship and brotherhood with people of different races and religions, and share the same Singapore nationality. Malaysia was different. The UMNO leaders in Kuala Lumpur (KL) — the central government—wanted one dominant race, i.e. Malay Malaysians, to enjoy special rights, while the Chinese, Indians and other citizens would forever be in a subordinate position. We fought that and disagreed with them. Eventually, we separated from them because it could not be settled. (Today 2017)

Secondly, Lee explained, "Singapore is a Chinese-majority country, in a Malay-majority part of Southeast Asia": 
In the 1960s, 50 years ago, Singapore had already been perceived as a "Third China". We were seen as a Chinese country, a proxy, a stooge for communist China, and not an independent player. If Singapore had been identified as a Chinese country, it would have caused problems with our neighbours. We would not have been able to live peacefully in Southeast Asia. So we had to make quite sure that people understood that we were an independent, multiracial country. (Today 2017)

PM Lee the younger next asked Singaporeans to remember that multiracialism was "not something natural, nor something which will stay there by itself" but the result of "very hard work, a lot of toil and sweat, and the gradual education and bringing together of people." He then proceeded to list the PAP policies that had achieved this end. First was the immediate post-independence focus on Anglophone education, which meant Singaporeans "used English as our common language, while ensuring a place for our mother tongues." Following this came the "common spaces and opportunities" that the government had created to bring people together, and its Ethnic Integration Policy, which from 1989 "mixed all races together in HDB [Housing Development Board] estates, so that there are no enclaves or ghettos in Singapore." Crucially, this policy, Lee noted, included the establishment of ethnic residential quotas for state-subsidized housing blocs and estates so that they replicated Singapore's overall racial "balance". "The policy has largely met its aim," the PM observed, "with every neighbourhood here a microcosm of society at large" (Today 2017).

Another key policy was the creation of Group Representation Constituencies (GRCs), which since 1988 have required all political parties to field teams of candidates that include Indian, Malay, or other ethnic minority representatives for elections in newly created super- 
constituencies. The purpose of this policy, Lee explained, was to ensure that "in Parliament we will always have minorities represented," it being officially assumed from the early 1980s (when the policy was first mooted) that Singaporeans have always voted, and are always likely to vote, along ethnic lines.

Finally, Lee noted that over the years Singaporean multiracialism had been preserved by strong government:

We came down hard on extremists-regardless of whether they were Chinese chauvinists or Malay, Indian or Hindu extremists — because they have to understand that this is what Singapore is, and this is how Singapore will act when racial chauvinists try to stir up sentiments against others. (Today 2017)

Today, prospective Singaporean citizens are introduced to this national narrative through a mandatory online and experiential training, which culminates with their naturalization ceremony, entitled the "Singapore Citizenship Journey." This journey inculcates in new citizens the "nation-building" milestones which have created today's prosperous cosmopolitan city-state as the PAP imagines them. At the National Museum and the Singapore Discovery Centre, nearly-citizens experience the tumultuous visceral horror of the ethnic riots between Chinese and Malays in Singapore in 1964, which in the official Singapore Story have become the key birth-trauma of the new nation and an official legitimization for the subsequent policies that the government has enforced (Singapore Citizenship Journey; see also Gest, this issue).

Critics in Singapore and beyond contend that the "elevation" of the 1964 riots to the status of national birth-trauma has inscribed "a belief in the primordiality of racial conflict" deep in the national consciousness and erased "the political contingencies" that created this 
event, so it becomes remembered as essentially racial rather than political in origin (Goh and Holden 2009, 7). They view the government's control over the press, and over freedom of speech and assembly - controls which are officially justified in terms of controlling a public sphere deemed liable to descend into primordial sectarianism - as brazen efforts to kill off dissent and so enshrine PAP rule in perpetuity. They see the PAP's commitment to breaking up ethnic enclaves, to ostensibly create in each neighbourhood a microcosm of Singapore's overall racial "balance", as intended to dilute and disperse the minority vote (see also Gest, this issue). They view the PAP's creation of GRCs and its continued shifting of electoral boundaries as policies which, in the name of multiracialism, cement its electoral dominance, especially given the evidence that Singaporeans have never historically voted along narrowly ethnic lines (Ang 2016). Undeniably, in a context in which the government's multiracial social engineering extends to where Singaporean citizens are permitted to live (and therefore, where they can vote), opposition parties have had trouble translating their share of the national vote into parliamentary representation. For instance, despite opposition MPs winning nearly 40 percent of the popular vote in the general election of 2011 (their best showing since independence), they ultimately made up a mere 6.9 percent (amounting to 6 seats) of elected MPs in the Singapore Parliament. ${ }^{4}$

But perhaps the most impactful criticism of PAP multiracialism has come from those within its political fold who embrace the party's original idealism rather than its subsequent practice. To encourage a greater range of parliamentary voices, the government introduced in 1990 a system of Nominated Members of Parliament (NMPs) selected by a committee headed by the Speaker of the House. In 2009, the NMP Viswa Sadasivan, a television broadcaster and broadcasting executive who had formerly worked within Singapore's state-controlled media, gave his maiden speech. Sadasivan moved the motion: "That this House reaffirms its commitment to the nation building tenets as enshrined in the National Pledge when debating 
national policies, especially economic policies." He then reminded parliament, phrase by phrase, of the central tenets of the Pledge, drawing attention to the creeping cynicism with which government policies in tension, if not at odds, with its original idealism were being greeted, especially by younger generations. As Sadasivan put it:

[O]ver the years we have, I feel, become very race conscious as a people. In almost everything we do we are reminded of, asked about our race.... All I am saying is that we need to study this practice carefully and in an open-minded manner, with a view to finding ways to amend or tweak the practices to better manage mixed signals that confuse. Many young people I have spoken to have highlighted this apparent contradiction with the "regardless of race" tenet of the Pledge. Principals and teachers too have raised this issue. (POS 2009)

Sadasivan's speech made an impact sufficient to merit a response from the then Minister Mentor Lee the elder. In what became one of his very last contributions to Singaporean parliamentary debate, Lee, having cancelled a scheduled session of physical therapy to ensure his reply was heard, rose from his seat to rebuke the nominated MP for arguments that were "false and flawed ... completely untrue ... with no basis whatsoever." In seeking to bring "this House back to earth," he reminded it that the National Pledge was an "aspiration," not an "ideology," and thus confirmed to the nation, as the headline in the Straits Times put it, his view that "Equality is an aspiration, it is not reality, it is not practical" (Straits Times, March 27, 2015).

For our purposes, among the policies identified by Sadasivan as contradictory to the Pledge - policies which included the exclusion of Malay-Muslims from senior roles in the Singapore Armed Forces, the limiting of government special assistance plans to Chinese 
schools, the sponsorship of ethnic-based self-help groups, and the PAP's assumption that Singaporeans were not ready for an ethnic minority Prime Minster-was the government's "need for us [the Singapore people] to maintain the current racial distribution in society" (POS 2009). We now return to this essential and yet, for some observers, contentious plank of Singaporean multiculturalism, and within it the role played by immigration over the last two decades.

An unsettled majority: Singapore's racialized governance of immigration

In the first two decades of Singapore's independence, immigration was not the heated political issue it would become. The island's population grew naturally, the result of a veritable babyboom stimulated by PAP-engineered prosperity. In 1965, Singapore's non-resident population stood at only 2.9 percent and it would remain at this low percentage until the late 1980s (Yeoh and Lin 2012). Immigration restrictions that Singapore's colonial government had introduced following World War Two, and especially following China's Communist Revolution of 1949, remained in place. They became tightened after Singapore's separation from the Federation of Malaysia and independence. Immigration was limited to skilled arrivals who would develop the national economy, whose specialist expertise and services were not available locally, and to families of existing residents and others permitted to settle on compassionate grounds (Saw 2012, 253).

By the late 1980s, however, Singapore's economic development demanded a policy change. The shift from manufacturing to high-tech and value-added activities, and the official drive to become a thriving "global knowledge hub," necessitated a concerted effort to recruit foreign talent. Simultaneously, an increasingly educated Singaporean population proved unwilling to undertake blue-collar jobs in construction, shipyards, sanitation, and domestic 
care. These challenges produced what Brenda Yeoh identifies as the city-state's' "bifurcated" immigration policy (Yeoh and Lin 2013). On the one hand, the government has targeted skilled migrants, whom it views as more valuable to Singapore in the long term, and to whom it has offered incentives for permanent settlement and naturalization; on the other hand, so as to feed the demands of industry, it has facilitated the creation of large-scale transient and "disposable" immigrant workforce, whose experience in Singapore remains, in a variety of ways, highly restricted (Yeoh and Lin 2013). Singapore's implementation of a patchwork system of immigration statuses might well also be understood as its attempt to negotiate the transnational labour movements of the global neo-liberal economy, as identified by Aihwa Ong (2006).

But Singapore's more liberal immigration policy from the late 1980s also stemmed from the unsettling forecasts its leaders began to receive from the start of that decade. These indicated that the island would soon be exposed to the double demographic challenge faced by many developed economies: declining fertility rates (which meant the existing population would not replenish itself through natural increase) combined with an increasingly ageing populace. In Singapore's first five years of independence, its Total Fertility Rate (TFR) was 3.65, well above the replacement-level rate of 2.1. However, by the years 2005 to 2010 , that rate had dropped to 1.25 (Jones 2013, 11). Crucially, this decline was most evident in Singapore's majority Chinese population, which in 2010 dropped to a TFR of 1.05 . Adding to the anxiety of Singapore's policy makers was the increasing number of skilled Singaporeans who chose to emigrate and renounce their citizenship (Yeoh and Lin 2013).

To forestall this trend, the government launched its first explicitly ethnic immigration push. In the process, it revealed itself as more candid regarding the racial anxieties propelling such a policy than it would be subsequently. In 1989, Prime Minister Lee Kuan Yew used his National Day Rally address to inform the nation that over the coming decade it would be 63,700 births per year short of replacing itself. As the Straits Times (August 21) reported, with 
accompanying charts and graphics, Lee announced that: "The extent of the shortfall would, however, be different for the different races. The Chinese would suffer the greatest deficit, 70,000, followed by Indians who would be short by 700. But, Malays, because of their higher fertility rate, would have 7000 more than was necessary to replace their number by 1999." To underline the ethnic dimensions of the challenge even more starkly, Lee produced figures from 1975-1988 that indicated that: "In all the deficit was about 121,000, with the greatest shortfall of 115,000 suffered by the Chinese, followed by 3,800 Indians and 2,400 Malays" (Straits Times, August 21, 1989).

Singapore's resulting immigration push was primarily aimed at Malaysian Chinese. In the 1990s, the number of Malaysian residents in Singapore rose by 55.8 percent, from 194,929 in 1990 to 303,838 in 2000, with 85 percent of this total being Malaysian Chinese (Nasir and Turner 2014, 26). Yet, the government also targeted Hong Kong Chinese, with 31,000 receiving Singapore PR status in 1991 and 33,000 in 1992. The plan to bring in Hong Kong Chinese had been hatched back in 1987, ten years before the British handover of the colony, after Lee had realized that Singapore was behind Australia and Canada in attracting such migrants. That same year, the government introduced a fast-track settlement and citizenship scheme for prospective Hong Kong arrivals which gave them "in principle" Singaporean permanent residency for up to ten years before they left the British colony, a status which became effective PR as soon as they arrived in Singapore, with citizenship obtainable after just two years' residence. An official publication sent to Hong Kongers the Singapore government targeted included other incentives: instant PR once they relocated, or relocated their families (ahead of their own arrival), or when they found employment or set up businesses in Singapore (Straits Times, May 14, 1988). Notably, for the first time, this immigration push was directed at technicians and other experienced white-collar workers in addition to graduate-educated professionals (Da Cunha 1994, 58-59). Since 2000, the liberalization of immigration has 
continued, with Singapore becoming an increasingly attractive destination for immigrants from the People's Republic of China (PRC). Official figures for this latest influx are kept a state secret (for reasons that will become clear shortly), but unofficial estimates placed the PRC population in Singapore by 2012 at between seven-hundred thousand and one million (Hong 2014).

The government's calibration of immigration, permanent residency and naturalization has meant that though Singapore's population has markedly expanded since independence, the ethnic distribution within it has remained roughly constant. In 1970, the resident population of the island was 77 percent Chinese, 14.8 percent Malay, 7 percent Indian and 1.2 percent "Other"; in 2015, it stood at 74.3 percent Chinese; 13.3 percent Malay; 9.1 percent Indian, and 3.2 percent "Other." Nonetheless, changes in the city-state's demography have in other ways been profound. Between 2000 and 2010, Singapore's transient, non-resident, population increased from 18.7 percent to 25.7 percent. Over the same decade, the number of Singapore PRs increased by on average 8.4 percent annually, rising from 8.8 percent of the total population to 14.3 percent. In 2011, Chinese made up 61.4 percent of this increased PR population, and Indians 20.4 percent. The latter figure has certainly been a factor in the overall rise in the Indian community to 9.2 percent of the total resident population, as opposed to 7 percent in 1970 (Yeoh and Lin 2012; Saw 2012, 61-65).

Clearly, the way Singapore's government has come to use ethnicity to determine immigration, permanent residency and naturalization sets it apart from the grand historical shift that, since 1945, has characterised most Western democracies. As Christian Joppke (2005) argues, Western liberal states have moved from "ethnically selective" to "non-ethnic, universalistic immigration policies" as their approach has fallen into line with their overall commitment to policies that do not "distinguish between people, be they citizens or aliens, along the ascriptive lines of ethnicity, national origin or race" (ix). In a system in which "the 
state may consider the individual for what she does, not for what she is," desirable immigrant criteria have been reduced to their skills and economic value (2-3).

This is not to say that in Western liberal states ethnicity no longer determines immigration, but rather that major changes have occurred in the way it determines immigration. Positive discrimination exists in the desire of some liberal states to incentivize the return of ethnic migrants deemed to belong to their nation's ethnic core, or in the preference for migrants deemed to hold close cultural, historical, and even spiritual affinities with the people of that core, affinities which enable them to more easily integrate. States such as France and Italy have not been above concurrently imposing conditions that make naturalization for minority peoples who do not belong to the national core, and their children, a much longer and more difficult process. Nonetheless, so Joppke argues, such ethnic determinants of immigrant selection are nested within, and subordinate too, a series of other criteria which are patently nonethnic in character (220-222, 240-245).

By comparison, Singapore's modern immigration policy harkens back to an era when ethnicity was the dominant defining criterion for immigration or exclusion. The United States Immigration Act of 1924, which included the National Origins Act and Asian Exclusion Act, established for the next forty years a system of ethnic immigration quotas based on the breakdown of the national population according to the ethnic categories and ratios of the 1890 Census. These quotas were designed, as one of the Act's architects put it, to "maintain the racial preponderance of the basic strain of our people and thereby to stabilize the ethnic composition of the population" (Senator David Reed, quoted in McFadden 1926). ${ }^{5}$

Public criticism of Singapore's population policy (to which we return shortly) has rarely extended to the government's use of immigration to stabilize the nation's ethnic composition. Where real pressure on its selective immigration approach has emerged, it has come from 
Singapore's regional trade partners. The call of our Today letter-writer Sum Siew Kee for more talented Indians to be allowed into Singapore, regardless of ethnic quotas, was prescient, as this issue subsequently generated international friction between India and Singapore. Indian software companies operating in the city-state, having seen the number of skilled Indian workers and PRs rise in Singapore in the first decade of the new millennium, then faced the sudden closing of the immigrant tap, despite Indian IT skills remaining in high local demand (Quartz, April 12, 2017). The Singapore authorities' check on Indian immigration, which coincided with the Indian proportion of the island's resident population threatening to climb above 10 percent, resulted in a formal complaint from the Indian National Association of Software and Software Companies to the Indian government. In early 2017, during a visit to India, Singapore's Deputy Prime Minister Tharman Shanmugaratnam responded by defending her sovereign right to control immigration, likening her desire to do so to that of Western liberal states across the developed world (Straits Times, July 23, 2017). What the Deputy PM neglected to note was that these liberal states no longer practice Singapore's system of ethnically calibrated immigrant selection, even if some of their citizens might wish that they would.

Currently, the Indian government appears to regard Singaporean restrictions on Indian immigration as in contravention of the Comprehensive Economic Cooperation Agreement that both nations signed in 2005. Indian labour mobility into Singapore is one of the two critical issues (the other being the freedom of Indian banks to operate in Singapore), which has meant the revised terms of the Agreement have remained under review, so far without resolution, since 2010 (Straits Times, April 4, 2017; Quartz, April 12, 2017). ${ }^{6}$

The racialized governance of migration: a discourse of necessary ratios 
Interestingly, while, as we have noted, Singapore's official commitment to maintaining racial "balance" has produced little domestic discussion, when it has been questioned the debate has been illuminating. For these occasions confirm that as much as geopolitical and economic anxieties have informed the state's ethnically selective immigration policy, it has been underpinned by deep-seated cultural, historical. and racial assumptions, embedded in a state imaginary long mired in a discursive essentialism left over from the colonial era. And the chief architect of such an imaginary, both during his lifetime and through the attitudes and ideas that have survived as his ideological legacy, remains Singapore's first prime minister Lee Kuan Yew - the visionary who, as his son recalled (Today 2017), was also an original author of the government's commitment to meritocratic multiracialism.

Lee Kuan Yew himself provided public evidence of the way this imaginary has influenced Singapore's immigration policy in August 1989, during his National Day Rally speech, when he justified Hong Kong Chinese immigration by detailing the ethnic dimensions of Singapore's population dilemma. Earlier that year, a PAP MP by the name of Goh Choon Kang had given a speech in Chinese, in which, as reported in the English-language Straits Times, he exhorted Chinese Singaporeans to "have more babies if there is to be balance in population growth among the various races" and spoke of "the very adverse effect on society" if "the Chinese birth rate continued to slide" (Straits Times 1989a). Chiam See Tong, at that time Singapore's sole elected opposition MP, took issue with such comments in parliament, chiding Goh for a "kind of racialist talk" that was "very bad for racial harmony in Singapore": "Because the Malays and the Indians in Singapore too will say that their respective populations will have to be increased. This kind of talk will lead to Chinese, Malay and Indian chauvinism and make our people more divisive."

In his rebuke of the PAP MP, Chiam also asked: 
What makes the hon. Member ... think that the ratio of Chinese $75 \%$, Malay $15 \%$, and Indian $8 \%$ contributes a balance of races in Singapore?... When you ask a Malay or an Indian what is meant by a balance of the various races, the Malays will tell you that the Malay population need to be increased to at least $331 / 3 \%$. The Indians will also tell you the same. And both of them probably want the Chinese population to be cut down to $331 / 3 \%$. So from their point of view, that is the real balance of races. (POS 1989)

Goh defended himself by explaining that the Chinese fertility problem was inevitably of greater concern to the government since Chinese were the majority ethnicity in Singapore. In the process, he cited the same worrying fertility statistics that Lee would subsequently deploy. Yet this merely spurred Chiam to challenge Goh's premise again:

Sir, on what basis does the Member ... think that the balance of races should be $75 \%$ Chinese, $15 \%$ Malays and $8 \%$ Indians? He says we must always keep to that kind of ratio, and since the Chinese birth rate is not replacing itself, we must push it up. On what basis? Who in Singapore decreed that the Chinese must be $75 \%$ and Malays must be $15 \%$ ? (POS 1989)

Lee Kuan Yew gave Chiam a direct answer to his question in speech to the nation some five months later. Lee, so the Straits Times reported, made clear "that the Government's stand was that the present racial balance will be maintained- 'it is a crucial stand,' he stressed." Lee then dealt with Chiam's “views about a shifting ratio of races and a possible composition of onethird each for Chinese, Malaya and Indians":

Let me tell you what I would think if I were an Indian. Why not 76 per cent Indians, 15 per cent Malays and 7 per cent Chinese? That is better still. But you know this is the real world. Let us just maintain status quo. And we have to maintain it or there will be 
a shift in the economy, both the economic performance and the political backdrop which makes that economic performance possible. (Straits Times 1989b)

"Mr Lee," the report continued, "said statistics showed that there will be significant differences in the economy of Singapore if the ratio were transposed." Lee was quoted as saying:

You look at the educational levels of the performers. It has got to do with culture, nature and so many other factors. But year after year, this is the end result. Let's leave well alone. The formula has worked.

We do not have to venture far to discover what Lee had in mind when he spoke of "culture," "nature," and the "so many other factors" that combined to dictate why, economically speaking, Singapore's ethnic formula needed to remain. Four years earlier, he had given a partial insight into his thinking when he had sparred in parliament with Joshua Benjamin Jeyaratnam, Singapore's only other opposition MP of that era (apart from Chiam). Lee, in replying to Jeyaratnam's demand for constitutional amendments to secure citizen rights along the lines of Western liberal states, called for the maintenance of a Singapore system that had worked and generated prosperity. Why had it worked, Lee asked (turning his speech into an opportunity to address "a younger generation of Singaporeans" whom he specifically hoped would "ask themselves what made Singapore work"):

Because we have a practical people whose cultures tell them that contention for the sake of contention leads to disaster. I have said this on many a previous occasion: that had the mix in Singapore been different, had it been $75 \%$ Indian, $15 \%$ Malays and the rest Chinese, it would not have worked. Because they [the Indians] believe in the politics of contention, of opposition. But because the culture was such that the populace sought a practical way out of their difficulties, therefore it has worked. (POS 1985) 
In this heated joute oratoire, Lee revealed his opinion that a key factor in Singapore's success was that the contentious Indian culture which had produced the oppositional Jeyaratnam, the descendant of Sri Lankan Jaffna Tamils, was shared by less than 10 per cent of the overall population. Yet, this claim formed only part of the racial imaginary that Singapore's founding father later admitted had developed in his mind over his political career, leading him from his youthful belief that all men were equal, to his later acceptance that environment, genes, and culture evidently made them not.

Harking back to the views of the British Resident John Crawfurd, one of Lee's beliefs was that Singapore's non-Chinese communities lacked industriousness. As Lee told a group of Straits Times journalists in the late 1990s:

At the very beginning, the Malays were not hardworking, nor were a lot of the Indians. We encouraged them to keep up. I'm not sure whether they will feel a little resentful, but I mean this is part of history. I know that it took a long time before the Malays accepted that they had to work hard because it was not in their culture. (Han, Fernandez, and Tan 1998, 187)

Lee was even happy to inform these journalists: "I have said openly that if we were 100 per cent Chinese, we would do better. But we are not and never will be, so we work with what we have" (181).

Lee's early speeches as prime minister referred to the environmental determinants of the superior industriousness of Singapore's Chinese. In 1967, he lectured foreign journalists on the "cultural pattern," determined by "many things, including climatic conditions," through which it was possible to demarcate nations in various parts of the Asia region. East Asia, Southeast and South Asia, Lee claimed, each had a "different tempo." East Asian nations were 
tougher, less soft, and more ruthless because of their distinct religious heritages (Lee 1967). In a speech at Canterbury University in New Zealand in 1965, he claimed of Southeast Asia as a whole:

[I]f you look at the region you will not find cultures which created societies capable of intense discipline, concentrated effort, over sustained periods. Climate, the effects of relatively abundant society and the tropical conditions produced a people largely extrovert, easy going and leisurely. They've got their wars, they have their periods of greatness when the Hindus came in the seventh and again in the 12th centuries, in the Majapahit and Srivijaya empires. But in between the ruins of Borobudur and what you have of Indonesia today, you see a people primarily self-indulgent. (Lee 1965a)

Addressing an audience at his Cambridge alma mater in 1971, Lee expounded on the civilizational differences between different parts of Asia which determined their respective paths to development:

It is in part the difference between the more intense and exacting Sinic cultures of East Asia and the less intense and less demanding values of Hindu culture in Southeast Asia, that accounts for the difference in industrial progress between Eastern and Southeast Asia. The softer and more benign Hindu civilization spread through Burma, Thailand and Laos and Cambodia, meeting the Sinic civilization on the borders of Vietnam, the Indo-Chinese Peninsula. (Lee 1971)

For Lee, the Sinic civilizations of East Asia-Korean, Japanese, Chinese and Vietnameseproduced "hard societies." The historical circumstances of migration to Singapore only bolstered the inherent ruggedness of its Sinic core: 
The Chinaman who came out to Southeast Asia was a very hard working, thrifty person, I mean he faced a tremendous stride because he faced pestilence, famine.... The capacity for hard work and sustained effort is something to be seen, to be believed. (Lee 1965b)

Viewed through this official lens_-and it is implausible to argue that between 1965 and 1990, Lee the elder was a peripheral ideologue, somehow not central to PAP thinking-Singapore's economic success necessitated the continued at least 75 percent dominance of its disciplined, pragmatic and ruthless Sinic core. Here was the powerhouse of the nation's industrial progress, comprised of a migrant stock resistant to the enervating impact of Singapore's tropical climate. The island's ethnic engine-room was supplemented by a less hard-working minority of Malays and a smaller minority of also less disciplined, sometimes highly contentious, Indians.

Given such pronouncements, we might well conjecture whether Lee imagined the national function of these two minorities to mostly lie beyond the industrial economic realm: Malays contributing to society through their ornamental cultural practices; Indians, likewise, through their "softer" civilization, ensuring Singapore's exotic diversity, yet perhaps also contributing through their predilection for making forceful arguments, in the state-prescribed contexts that warranted them (the courthouse, the parliament and the heavily monitored press room).

\section{Racial "balance" and the future of Singaporean multiculturalism}

In 1965, the year that Singapore gained independence, the United States introduced a new Immigration and Nationality Act that ended the practice of national-origin quotas and banned discrimination in the issuing of visas on the grounds of "race, sex, nationality, place of birth or 
place of residence." Robert Kennedy, who along with his brother John F. Kennedy keenly supported the Act, declared in 1964: "Everywhere else in our national life, we have eliminated discrimination based on one's place of birth. Yet this system is still the foundation of our immigration law" (quoted in Fitzgerald and Martin 2015). The Act was announced on the floor of the House of Representatives with the words: "Just as we sought to eliminate discrimination in our land through the Civil Rights Act, today we seek by phasing out the national origins quota system to eliminate discrimination in immigration to this Nation composed of the descendants of immigrants" (Fitzgerald 2014, 119). In the years which followed, the United States experienced a demographic revolution that saw legal European immigration, which had made up 60 percent of the total in the 1950s, decline to 22 percent by the 1970s. Meanwhile, Asian migration, which made up 6 percent in the 1950s, rose to 35 percent by the 1980 s and to 40 percent by 2013 (Fitzgerald and Martin 2015).

A comparison with Singapore is worth highlighting because its leaders, as we have seen, have sometimes justified her immigration controls as merely paralleling the response of the United States and other Western liberal democracies to the shared reality of intensified global population movements (Straits Times, July 23, 2017). But this effort to draw parallels masks two very distinct historical trajectories. Although the Singapore government still exhorts its people to pledge themselves "as one united people, regardless of race, language or religion" to build "a democratic society based on justice and equality," it has, over the last 30 years, deployed immigration as a tool to ensure Chinese demographic hegemony. This hegemony, so independent Singapore's founding father claimed, was at the heart of the successful Singapore "formula". Singapore owed its economic success to the cultural, historical, and civilizational characteristics that Sinic civilizations possess in greater abundance than their Asian rivals.

In one obvious manner, the "logic" of maintaining Chinese demographic hegemony might be said to have paid dividends. Between 1990, when Singapore first sought to shore up 
its declining Chinese population through immigration, and the year 2012, bilateral trade with China grew from USD 2.8 billion to USD 69.3 billion, a twenty-four-fold increase (Hong 2014, 1228). Nonetheless, the cost in terms of the social cohesion the Singapore government takes pride in has been notable. Immigration, intended to maintain the racial "balance" in Singapore and therefore social stability, has achieved the very opposite - no doubt, partly because the government's approach has been rooted in such essentialist understandings of ethnicity.

From the very outset, the public discontent which accompanied the liberalizing of immigration into Singapore was as much expressed by Singaporean Chinese as by Singaporean Malays and Indians. The arrival of Hong Kong Chinese in the late 1980s created general anxieties over aggravated job competition, depressed wages, and failed integration (Da Cunha 1994, 58-59). Local fears intensified with the subsequent huge increase in PRC immigration. Tensions reached their height with the dissemination of the government's Population White Paper of 2013, which promised the annual creation of thirty thousand new permanent residents and twenty-five thousand new citizens to supplement the existing resident population and thereby compensate for declining birth rates (NPTD 2013). In a city where foreign-born migrants already made up two out of every five people, and their arrival was blamed for overcrowding, creaking infrastructure, wage stagnation, spiralling housing costs, and unemployment, the White Paper produced widespread condemnation. In a city notable for the absence of political demonstrations, roughly four thousand people gathered at Hong Lim Park on February 16, 2013, to protest the White Paper and chant slogans such as "Singapore for Singaporeans" (Straits Times, January 9, 2017). Two years later, the Financial Times reported that tensions which had simmered since 2000 were now boiling over to make immigration the "flashpoint" issue of the coming general election in 2015 (September 7, 2015).

While such protests might appear directed against overall immigration into Singapore, there has been a clear ethnic target. As Brenda Yeoh argues, anti-immigration sentiment has, 
since the start of the new millennium, manifest itself in deeply ethnicized popular narratives primarily directed at PRC arrivals (Yeoh and Lin 2013). Ignoring the state-engendered bifurcation of such migrants into skilled would-be residents and transient "disposable" labour, these narratives assert the assumed "red carpet" treatment that all PRC arrivals receive and their alleged "stepping stone" attitude to permanent residency and naturalization (in which they view Singapore as merely a passport to further social, political and economic goods, and to further destinations). Across social media, PRC immigrants have been caricatured as uncouth, unhygienic, loud, and profoundly self-interested. In response, they have produced their own online racism aimed at Singapore-born Chinese (Yeoh and Lin 2013, 32-44).

The irony of the Singapore case is that the island's political elite, unsettled by declining local Chinese fertility rates, perturbed by the economic implications of a changing ethnic distribution, and then resorting to ethnically selective immigration pushes to avert it, has unsettled the Chinese majority it has sought to demographically bolster and protect. Indeed, it might be argued that social divisions within Singapore's Chinese majority now run as deep, if not deeper, as those latent divisions the state has long assumed to exist between Singapore's Chinese and its Malay and Indian communities, and which it believes necessitate such strict policing.

In a further irony, one that especially illuminates the current meaning of Singaporean multiculturalism, local discontent with PRC immigration has manifest itself in popular activism intended to clearly demarcated the common characteristics that define Singaporean national identity - including speaking English, compulsory national service (for adult males) and diet and therefore what is culturally required to gain entry. In 2011, a dispute between a migrant PRC family and a Singaporean Indian family over the smell of curry emanating from the latter's home exploded across local media, especially after it was revealed that the resolution of this so-called "curry dispute" required that the Indian family spiced things up only when their 
Chinese neighbours were out. The incident inspired a grassroots campaign called "Cook and Share a Pot of Curry," which called on Singaporeans to invite foreigners to share this "national" dish as a means "to celebrate curries as part of our way of life and to share this celebration with those who are new to our shores" (Straits Times, August 17, 2011; New Paper, August 14, 2011). On social media, some sixty thousand Singaporeans confirmed their support and participation in this event. Meanwhile, local outrage over the "curry incident" was sufficient enough for K. Shanmugam, then Minister of Law, to clarify that the disagreement had occurred seven years earlier, and in fact been resolved through both families' voluntarily agreeing to the new arrangement that subsequently caused such public outrage (Straits Times, August 17, 2011).

Nonetheless, fraught relations between PRC arrivals and Singapore-born nationals have continued to make immigration the island's most contentious political issue. Since the public outcry generated by the 2013 White Paper, the PAP has rolled back its population growth plans, wary of repeating its 2011 general election performance (during which immigration policy was understood to be one of the key policies that led to its lowest vote share, of 60.4 percent, since independence). In the 2015 general election, the government, having placed new curbs on migrant entry and work visas, recovered much of its lost electoral support. As one Singaporean social commentator put it in 2017, "for all intents and purposes, it seems that the Population White Paper is on ice and few politicians now mention it in public." Yet, as the same commentator also noted, Singapore's TFR remains unchanged, the "number of working-age Singaporeans will start to decrease from 2020 ... the citizen population will start to decline in 2025" (Cheng 2017).

How, in the future, Singapore's leaders approach these ongoing demographic challenges (which already appear to have affected national productivity) will have a significant bearing on the ultimate meaning of Singaporean multiculturalism - the fundamental ideology 
for some and idealistic aspiration for others, on which, according to the official Singapore Story, the independent city-state has been built. To maintain the current ethnic composition of the resident population will require further Chinese immigration. But which Chinese will become Singapore's new PRs and citizens? Since the liberalization of Singapore's immigration controls in the late 1980s, influxes of Malaysian Chinese have generated far less local resentment than arrivals of Hong Kong Chinese and subsequently PRC immigrants. In official discourse and more generally, Malaysian Chinese are presumed to (and often do) share historical, cultural, and familial ties with Singaporean Chinese. Malaysian Chinese residents in Singapore, most of whom would pass the "curry test," have long been classified under its labour policies as "traditional source workers" and given preferential treatment in terms of housing and employment (Lam and Yeoh, 2004, 148). ${ }^{7}$ However, this traditional immigration source is in danger of drying up. A falling TFR amongst Malaysian Chinese, combined with their emigration abroad (including to Singapore), not to mention higher fertility amongst Malaysia's Malay majority, has seen their population strength drop from 37.2 percent at the point of national independence in 1957 to 24 percent in 2013, with the same Chinese population predicted to drop below 20 percent by 2030 (Straits Times, January 24, 2017).

One future policy might be for the Singapore government to end its ethnically selective approach to immigration, to forsake the maintenance of the present racial "balance", to throw off the vestiges of a colonial racialism that has justified such ratios, and to instead embrace, as our Today correspondent Sum Siew Kee argued, "talented migrants regardless of race"embrace, indeed, the idea once mooted by S. Rajaratnam, the author of Singapore's National Pledge that: "Being a Singaporean is not a matter of ancestry. It is conviction and choice" (as quoted in PAP, 2013). But whether a state that has invested so much to preserve Singapore's dominant Chinese-ness over the last three decades, and evidently reaped huge economic 
rewards, could imagine such a colour-blind rethink of immigration, settlement and citizenship remains to be seen.

It ought finally to be noted that were such a policy change ever to arrive, the Singapore government would, in theory, appear well equipped to manage its impact. Four years before the 2013 Population White Paper and resulting protest, the government launched its National Integration Council, with the mission (as its website states) of helping "newcomers adapt to the Singaporean way of life, including helping them better understand local cultures and social norms." Singapore's Armed Forces Volunteer Corps now enables PRs and new citizens to (as its own website states) participate in and "deepen their understanding and ownership of National Defence"; new citizens born outside Singapore have been observed to be leading participants in the Volunteer Corps' grassroots activities. ${ }^{8}$ Various grassroots organizations now exist that promote racial harmony and equality, and thereby ensure this remains a central national ideology (not merely an aspiration). ${ }^{9}$ Indeed, while this essay has emphasised the gulf between Singapore's official practices of multiculturalism and its foundational idealism, objections to the state's racializing policies and the emergence of such grassroots activism point to how deeply within the wider populace the idea of "one united people, regardless of race, language or religion" still runs.

\section{References}

Ang, Michael Y. P. 2016. "Do Singaporeans Really Vote Along Racial Lines?” The Diplomat, March 3.

Barr, Michael D., and Zlatko Skrbis. 2014. Constructing Singapore: Elitism, Ethnicity and the Nation-building Project. Copenhagen: NIAS Press. 
Buckley, Charles Burton. [1902] 1984. An Anecdotal History of Old Times in Singapore.

Singapore: Fraser and Neave.

Cheng, Calvin. 2017. “The Population White Paper - Time to Revisit and Unpopular Policy?” Straits Times, January 9.

Chua, Beng Huat. 2003. "Multiculturalism in Singapore: An Instrument of Social Control." Race and Class 44 (3): 58-77.

Crawfurd, John. 1830. Journal of An Embassy from the Governor-General of India To the Courts Of Siam And Cochin China. Vol. 1. London: Colburn and Bentley.

Da Cunha, Derek. 1994. Debating Singapore: Reflective Essays. Singapore: ISEAS.

Fitzgerald, D. S. 2014. Culling the Masses: The Democratic Origins of Racist Immigration Policy in the Americas. Cambridge, MA: Harvard University Press.

Fitzgerald, D. S., and David Cook-Martin. 2015. "The Geopolitical Origins of the U.S. Immigration Act Of 1965.” Migration Policy Institute, February 5.

https://www.migrationpolicy.org/article/geopolitical-origins-us-immigration-act-1965.

Frost, Mark, and Yu-Mei Balasinghamchow. 2009. Singapore: A Biography. Singapore: Hong Kong University Press.

Furnivall, J. S. 1939. Netherlands India: A Study in Plural Economy. Cambridge, MA:

Cambridge University Press.

Goh, Daniel P. S., and Philip Holden, with Matilda Garbrielpillai and Gaik Cheng Khoo. 2009. Race and Multiculturalism in Malaysia and Singapore. Abingdon: Routledge.

Harper, T. N. 1997. "Globalism and the Pursuit of Authenticity: The Making of a Diasporic Public Sphere in Singapore.” Sojourn 12 (2): 261-292.

Hong, Liu. 2015. "Beyond Co-ethnicity: The Politics of Differentiating and Integrating New Immigrants in Singapore.” Ethnic and Racial Studies 37 (7): 1225-1238. doi:10.1080/01419870.2014.892630. 
Hill, Michael and Lian, Kwen Fee. 1995. The Politics of Nation Building and Citizenship in Singapore. Abingdon: Routledge.

Jones, Gavin. 2013. “The Population of Southeast Asia.” Asia Research Institute Working Paper No. 196. http://www.ari.nus.edu.sg/wps/wps13_196.pdf.

Joppke, Christian. 2005. Selecting by Origin: Ethnic Migration in the Liberal State.

Cambridge MA: Harvard University Press.

Kwang, Han Fook, Warren Fernandez, and Sumiko Tan. 1998. Lee Kuan Yew: The Man and His Ideas. Singapore: Singapore Press Holdings.

Kymlicka, Will. 1989. Liberalism, Community and Culture. Oxford: Oxford University Press.

1995. Multicultural Citizenship: A Liberal Theory of Minority Rights.

Oxford: Oxford University Press.

Lam, Theodora, and Brenda Yeoh. 2004. "Negotiating 'Home' and 'National Identity': Chinese-Malaysia Transmigrants in Singapore.” Asia Pacific Viewpoint 45 (2): 141-164. Doi: https://doi.org/10.1111/j.1467-8373.2004.00235.x.

Lee Kuan Yew. 1965a. Transcript of Speech to Students of Canterbury University Christchurch, 15 March. National Archives of Singapore.

http://www.nas.gov.sg/archivesonline/speeches/record-details/7da38647-115d-11e3-83d5$\underline{0050568939 \mathrm{ad} .}$

$.1965 \mathrm{~b}$. Transcript of Meeting in the Trade Union Hall, Adelaide, 30 March.

National Archives of Singapore.

http://www.nas.gov.sg/archivesonline/data/pdfdoc/LKY19650330a.pdf. .1967. Transcript of Speech at the Foreign Correspondents Association

Dinner, Tokyo, 21 March. National Archives of Singapore. 
http://www.nas.gov.sg/archivesonline/speeches/record-details/7435d1f0-115d-11e3-83d5$\underline{0050568939 \mathrm{ad} .}$ .1971. "East and West, the Twain have Met." 8 November. National Archives of Singapore.

http://www.nas.gov.sg/archivesonline/data/pdfdoc/lky19711108.pdf. 2009. Speech by Minister Mentor Lee KuanYew at Tanjong Pagar 44th

National Day Celebration Dinner. 13 August. Prime Minister's Office Singapore.

http://www.pmo.gov.sg/newsroom/speech-minister-mentor-lee-kuan-yew-tanjong-pagar44th-national-day-celebration-dinner.

Low, Kelvin E.Y. 2014. Remembering the Samsui Women: Migration and Social Memory in Singapore and China. Vancouver: UBC Press.

McFadden, F. J. 1926. "Quota control and the national origin system.” Editorial Research Reports 1926. Vol. IV. Washington, DC: CQ Press.

http://library.cqpress.com/cqresearcher/cqresrre1926110100.

Montsion, J. M. 2009. "Relocating Politics at the Gateway: Everyday Life in Singapore's Global Schoolhouse.” Pacific Affairs 82 (4): 637-656.

doi: https://doi.org/10.5509/2009824637.

NPTD (National Population and Talent Division). 2013. A Sustainable Population for a Dynamic Singapore.

Nagy, Stephen Robert. 2014. "Politics of Multiculturalism in East Asia: Reinterpreting Multiculturalism.” Ethnicities 14 (1): 160-76.

Nasir, K. M, and Bryan Turner. 2014. The Future of Singapore: Population, Society and the Nature of the State. Abingdon. Routledge.

Ong, Aihwa. 2006. Neoliberalism as Exception: Mutations in Citizenship and Sovereignty. Durham, NC. Duke University Press. 
PAP. 2013. "White Paper is our Collective Future.” PAP News and Commentaries. 8 February.

Parliament of Singapore. 1985. Official Reports - Parliamentary Debates (Hansard). Debate on President's Address. 1 March. https://sprs.parl.gov.sg/search/topic?sittingdate=1-31985\&htmlfilename=005_19850301_S0005_T0005. 1989. Official Reports - Parliamentary Debates (Hansard). Annual Budget

Statement. 14 March. http://sprs.parl.gov.sg/search/report?sittingdate=14-3-

1989\&htmlfilename=010_19890314_S0002_T0002\&searchfullreport=false $\&$ fromday $=\&$ fro mmonth $=\&$ fromyear $=$ 2009. Official Reports - Parliamentary Debates (Hansard). Nation Building Tenets (Motion). 18 August.

https://sprs.parl.gov.sg/search/topic?sittingdate $=18-8-$ $\underline{2009 \& \text { htmlfilename }=019 \_20090818 \_S 0005 \_ \text {T0003. }}$

Raffles, Sophia. 1835. Memoir of the Life and Public Services of Sir Thomas Stamford Raffles. Vol. 1. London: James Duncan.

Rahim, Lily Zubaidah. 2010. Singapore in the Malay World: Building and Breaching Regional Bridges. Abingdon: Routledge.

Saw Swee-Hock. 2012. The Population of Singapore. Singapore: ISEAS.

SAF Volunteer Corps. Ministry of Defence website. Accessed 27 August 2019. https://www.mindef.gov.sg/oms/safvc/. Singapore Citizenship Journey. National Integration Council website. Accessed 13 June 2018.

https://www.nationalintegrationcouncil.org.sg/citizenship/singapore-citizenship-journey.

Straits Times. 1989a. "More Chinese babies for balance, says MP.” March 14. 
. 1989b. "Entry of Hongkongers won’t upset racial mix.” August 21.

Sun, Shirley Hsiao-Li. 2012. Population Policy and Reproduction in Singapore: Making

Future Citizens. Abingdon: Routledge.

Teo, Chee Hean. 2010. DPM's Speech on Population at the Committee of Supply. National Archives of Singapore.

http://www.nas.gov.sg/archivesonline/data/pdfdoc/20100315003/dpm's_speech_on_populatio n_at_cos_20100304.pdf.

Today. 2017. "In Full: PM Lee on Race, Mutliracialism and Singapore's place in the world." 29 September.

Turnbull, Margaret. 2009. A History of Modern Singapore, 1819-2005. Singapore: NUS Press.

Vadaketh, S. T. 2015. “GE2015: Final thoughts (3 of 4).” Musings from Singapore blog. https://sudhirtv.com/2015/09/10/ge2015-final-thoughts-3-of-4/.

Vasu, Norman. 2012. "Governance through Difference in Singapore.” Asian Survey 52 (4): 734-753. doi: 10.1525/as.2012.52.4.734.

Yeoh, Brenda, and T. C. Chang. 2001. "Globalising Singapore: Debating Transnational Flows in the City." Urban Studies 38 (7): 1025-1044.

Yeoh, Brenda. 2003. Contesting Space in Colonial Singapore: Power Relations and the Urban Built Environment. Singapore: NUS Press.

Yeoh, Brenda, and Lin Weiqiang. 2012. "Rapid Growth in Singapore's Immigrant Population Brings Policy Challenges.” Migration Policy Institute. 3 April. https://www.migrationpolicy.org/article/rapid-growth-singapores-immigrant-populationbrings-policy-challenges. 
Globalizing Nation-State." Asia and Pacific Migration Journal 22 (1): 31-53. doi:

https://doi.org/10.1177/011719681302200103. ${ }^{1}$

\footnotetext{
${ }^{1}$ Since Singapore's independence in 1965 , the ethnic distribution in its resident population has remained relatively stable, with Chinese making up from 74 to 77 percent of the total, Malays comprising between 12 and 15 percent, and Indians between 7 and 9 percent.

${ }^{2}$ Unlike in other contexts, permanent residency in Singapore involves certain obligations to the state and can therefore be understood as a form of quasicitizenship or step towards full citizenship. Most notably, secondgeneration male PRs are required to undertake national military service along with young male Singapore citizens, unless they choose to renounce their PR status.

${ }^{3}$ The prime minister gave this speech in the context of public displeasure at his government's decision not to hold an open election for the presidency, but to reserve this appointment for a Malay candidate. He made this decision on the grounds that it maintained the Singaporean principle of multiracialism.

${ }^{4}$ Such criticisms are regularly aired on online independent political forums in Singapore, such as The Online Citizen, https://www.theonlinecitizen.com/.

${ }^{5}$ It must be granted that modern Singapore, unlike most Western liberal states, does not have the historical legacies of slavery, segregation, and colonial rule to recompense for through its postcolonial immigration policy. Nonetheless, its official determination to maintain a stable ethnic composition on the island - a racial "balance"" in which the preponderance of the Chinese majority remains steadfast and undiminished — has clear global parallels and antecedents.

${ }^{6}$ The second review of the agreement concluded in May-June 2018, after a hiatus of eleven years. It was referred to by the Indian prime minister as "not our destination, it is just a halt" (The Economic Times, June 1, 2018).

${ }^{7}$ For example, Malaysian Chinese who emigrate to Singapore hold the right to work in all economic sectors and not to be considered Singaporean PRs when applying to purchase HDB resale flats.

${ }^{8}$ I am grateful to Theophilus Kwek for this observation.

${ }^{9}$ See, for example, the activities of OnePeople.sg.
} 